\title{
Environmental characterization of a fluvian lagoon ecosystem (Pom-Atasta, Campeche, Mexico) as a critical manatee habitat
}

\author{
G. Acevedo-Olvera, A. Delgado-Estrella, M. del R. Barreto-Castro \\ \& E. Nuñez-Lara \\ Facultad de Ciencias Naturales, UNACAR, Mexico
}

\begin{abstract}
Mexico has a great diversity of aquatic ecosystems. The Pom-Atasta fluvial system lagoon is part of the Flora and Fauna Natural Protected Area: Laguna de Terminos. It is a region with large areas for manatee (Trichechus mananatus manatus) distribution. This species was included in the list of Mexican species at risk, (NOM-059- and IUCN). In 2013, monitoring was conducted during three seasons; rainy, dry, and north wind. The visual recording of merely 3 animals was blamed on the increasing use of the coastal shore by human activity; usage that has fragmented many areas that were formerly occupied by manatees. Their habitat is now shared with development areas and anthropogenic activity.

There are large amounts of organic matter found in this lagoon system; a result of the numerous tributaries of the rivers. The minimum salinity $(0.32 \%)$, indicates that lagoons have a strong freshwater influence. Some sites are observed with salinity of not more than $12 \%$. Oxygen concentrations ranging from 4.2 to $11.3 \pm 1 \mathrm{mg} / \mathrm{l}$. The average turbidity was $60 \pm 10 \mathrm{~cm}$; $\mathrm{pH} 8.5 \pm 0.5-$ $9.76 \pm 1$; the average temperature was 28 to $30 \pm 3^{\circ} \mathrm{C}$; the average depth was $2.5 \pm 3 \mathrm{~m}$. The vegetation condition plant species such as Pontederia cordata, Pontederia rotundifolia, and Eichhornia crassipes were found with traces of manatee browsing. Many studies have recorded those plant species as manatee food. They can also be seen as an indicator of water quality. There has been an adverse change in the available habitat caused by the influence of human communities. This influence is expected to negatively affect the habitat and the many species that occupy it, especially the manatees. They are in great danger of disappearing in this area.
\end{abstract}

Keywords: antropogenyc, habitat, fluvian lagoon, manatee. 


\section{Introduction}

Mexico has a great diversity of aquatic ecosystems, (rivers, lakes, lagoons, cenotes, etc.), habitats with species that are physically and biologically related to the hydrological regime. In recent years there have been studies of these subjects in order to establish site priorities such as reserves of water, all based on scientific, technical, social and economic data. Results show that it is feasible to estimate a sustainable balance of water between the different objectives of environmental conservation, social functions and other factors which apply pressures on the normal water flow resource. There is the need to incorporate environmental considerations within the processes of the management of water resources so that we can reduce ecological fragility, and achieve a better adaptation to climate change [1].

Pom-Atasta is a lagoon system associated with the Protected Natural Area of Flora and Fauna Laguna Terms, located $30 \mathrm{~km}$ west of Ciudad del Carmen, Estado de Campeche. The region is located between the coordinates $18^{\circ} 33^{\prime}$, $18^{\circ} 38^{\prime}$ north latitude and $92^{\circ} 01^{\prime} 92^{\circ} 14^{\prime}$ west longitude. It is a region with the availability of biologically rich water. The ecological importance of low water pressure, (slowly moving water), in large areas is basic for distribution of manatees (Trichechus manatus mananatus). Important to sites for conservation are food, and the availability of the variety of plants associated with manatee diet. Present here are favorable conditions for building water reservoirs to ensure flows for ecological protection under the terms of the National Water Law. Manatees are a flagship species included in the list of species at risk of NOM 059 [2], in the Red Book of IUCN [3]. The manatee has symbolic cultural features reflecting the interest of the local conservation community for these species. Threatening the area is the increasing use of the coastal strip to human activity which has fragmented, damaged, or destroyed many areas that were formerly occupied by manatees. Their habitat includes marine lagoon ecosystems and riverbanks [4] which are now shared with numerous areas of urban development, fisheries activities and agriculture. Habitat being affected by industrial activities of the oil industry, and wastewater discharges can cause diseases in manatees. Other habitat impacts are those associated with deforestation of mangroves and river inputs that collect contaminants from their drainage basins namely nutrients from agricultural and livestock activities, all carried over from the riverbanks.

\section{Methods}

During 2013 and early 2014 interviews and surveys were conducted in the fluvial system of the Pom-Atasta lagoon (Fig. 1). The finding of traces of manatee sightings and evidence of the "fed upon" vegetation, (grazing) were data included in the surveys. During each survey records were made of individual manatees and the recording stations' environmental parameters such as water depth, water temperature, (thermo-sounder), salinity (refractometer), and turbidity, (Secchi disk). Throughout the survey two observers were placed in the 


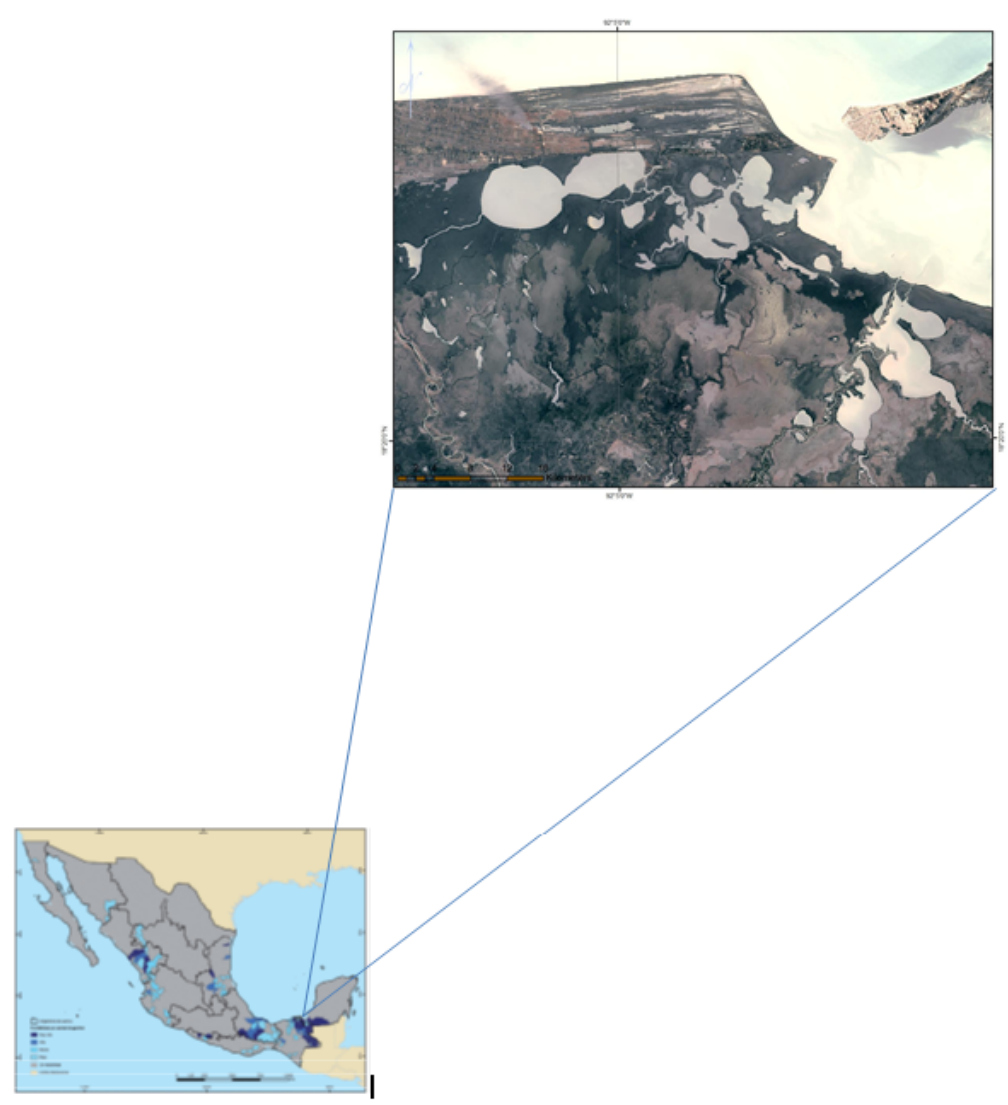

Figure 1: Study area.

bow of the boat that recorded the presence of animals when they were sighted breathing out or, when they were floating, looking for feed. In each sighting or plant grazing site the geographical position (GPS) was recorded. The whole observation route was kept at low speed $(<10 \mathrm{~km} / \mathrm{h})$ to ensure the registration of animals and avoid startling them. Simultaneously an underwater scanning was performed with a "sidescan" sonar. A "Hummingbird Fish Finder" and a GPS 998cx SI Combo was used to locate the submerged manatees, thus adjusting the recorded data to more realistic estimates of relative abundance. These methods have been used in rivers of Tabasco [5], and Chiapas [6], giving good results.

In an artificial canal located in the lagoon of Pom, sediment samples were taken with Van Veen dredge in areas where manatees possibly feed. The samples, once in the laboratory, were subjected to the granulometric classification and nutrition analysis to determine the amount organic matter in each. Vegetation samples that were collected were label identified then subjected to biochemical and bromatological tests such as extraction and quantification of total lipids [7]; amended by Izquierdo, Total Protein [8], Total Carbohydrate [9], 
Pigments: Chlorophyll A, Chlorophyll B and Carotenoids (Acetone method 80\% [10]), Moisture and Ash [11] for considering them as potential food sources to the manatees that inhabit the lagoon system.

\section{Results}

Only two manatees were observed as a result of the fieldwork. The first manatee was sighted near the "Zacatal" bridge. The second manatee was sighted in the artificial channel at Pom Lagoon. $55 \mathrm{~km}$ were traveled in obtaining each of the two sightings which gives a result of $0.2 \mathrm{ind} . / \mathrm{km}$. Additionally, but not included in the result factor of 0.2, a manatee skeleton was found in the lagoon of Atasta. Fishing nets were observed along the river mouth of Pom Lagoon during the surveys. The nets were observed at different points along the artificial canal, coincidentally, where the plants with signs of manatee grazing were found.

The physicochemical parameters recorded during this study have shown a salinity of $0.32 \mathrm{ppm}$, which is an indication of the strong influence of fresh water in the area. Some other sites salinity levels of not more than $12 \mathrm{ppm}$ were recorded. These environmental conditions were optimal for the manatee's requirements.

The oxygen concentrations ranged from 4.2-11.3 $\pm 1 \mathrm{mg} / \mathrm{l}$. Average turbidity was $60 \pm 10 \mathrm{~cm}$, pH was from 8. $-9.76 \pm 1$, water temperature ranged from 28 to $30 \pm 3^{\circ} \mathrm{C}$, average water depth was $2.5 \pm 3 \mathrm{~m}$. The classifications of sediments were fine sands. The content of organic matter along the canal was $14.5 \%$ at the mouth of the lagoon, and $16.1 \%$ in the channel, with an average value of $25 \%$, being the highest value in the center of the lagoon. The center of the lagoon is where the plants associated with manatee diet were collected including the plants in which traces of browsing were identified. Observed and collected was Pontederia cordata, an aquatic species belonging to the family Pontederiacea, a native of the American continent. As an emerging plant grows, that is, under flood conditions, its growth generally depends upon the plant stem to carry oxygen to the roots. In addition to flooding conditions carrying nutrients to the plants, the species is influenced by soil fertility. This is shown by Pontederiacea's tendency to grow in the most fertile bays of the USA-Canada Great Lakes region.

Table 1 presents the biochemical and chemical composition of the sampled vegetation in the channel which is potentially a part of the diet of the manatee. Other plants sampled cited in previous studies were Pontederia rotundifolia, Eichhornia crassipes [12].

\section{Discussion}

Although there are no recent previous studies in terms of the density and distribution of manatees in the lagoon system, historical records have indicated a decrease in the number of individuals due to poaching. Our study in which only two animals were observed over a year in this area strongly suggests poaching to be a factor for such low numbers of observations. Additional information in the 
Table 1: Biochemical profiles of vegetation considered as manatee's food.

\begin{tabular}{|l|c|c|c|}
\hline & $\begin{array}{c}\text { Pontederia } \\
\text { cordata }\end{array}$ & $\begin{array}{c}\text { Pontederia } \\
\text { rotundifolia }\end{array}$ & $\begin{array}{c}\text { Eichhornia } \\
\text { crassipes }\end{array}$ \\
\hline Lipids \% & 31.4 & 23.1 & 25.9 \\
\hline Proteins \% & 10.9 & 8.3 & 8.3 \\
\hline Carbohydrates \% & 2.4 & 2.5 & 17.1 \\
\hline Clorophyll A \% & 6.9 & 9.3 & 9.7 \\
\hline Clorophyll B \% & 5.3 & 6.2 & 9 \\
\hline Carotenoids \% & 4.2 & 3.8 & 14.5 \\
\hline Ashes \% & 10.5 & 14.4 & 5.0 \\
\hline Moisture \% & 6.4 & 2.2 & \\
\hline
\end{tabular}

form of comments from the interviewed villagers of Atasta is testimony to the decreased number of manatee sightings in recent years. Years past, it was common to observe manatees near urban areas engaged in various activities, even feeding. Classification of sediments as to sediment type and amount of organic matter obtained in the lagoon system matches with prior studies [13]. The availability and quality of vegetation is very important to qualifying a feeding site for manatees. The values of lipids, proteins, carbohydrates, pigments, ash and moisture for Pontederia rotundifolia and Eichhornia crassipes plants considered as food for manatees are very much like the values in previous studies [14]. Found with traces of manatee browsing, the Pontederia cordata, is an indicator that the availability of food in the area making it very suitable for the preservation of the species. Linked physical and chemical environmental factors such as salinity, temperature and oxygen percentage also indicate these water the suitable place for a manatees' reserve.

\section{Conclusions and recommendations}

The Pom-Atasta lagoon system due to their topographical features and the diversity of its current vegetation can be considered for a manatee and a manatee habitat protection area. Urgency for this area to be established as a reserve is tantamount.

* This lagoon system is ideal for the establishment of groups of manatees. Current habitat conditions; minimal salinity water; the presence of large quantities and varieties of the aquatic vegetation known to be in the 
manatee diet, make this area prime for a habitat reserve. In this area the many presently occurring environmental degradation problems such; as building and maintaining artificially dredged channels; the presence of nylon nets that cross the transit ways of manatees can easily be mitigated and then monitored. More difficult to mitigate are the environmentally degrading activities of the dumping of solid and liquid contaminants along the tributary rivers; population growth with its accompanying impacts; and industrial activity (oil) in the region. Being a designated protected area does not guarantee the sustainable conservation of habitat. Manatees are in serious danger of disappearing. It is urgent that measures are quickly taken for compliance management plans and monitoring of the areas where manatees have been seen performing different activities.

* Routine inspections on the placement of nylon nets in which there may be by catch species.

* Strategies for locating stranded animals.

\section{Acknowledgements}

We want to thank to the PROFOCIE 2014 for the financial support in elaborating and presenting this paper and to Michael Rudge for the translation assistance.

\section{References}

[1] SEMARNAT. Identificación de reservas potenciales de agua para el medio ambiente en México. Comisión Nacional del Agua.junio del 2011. México, Distrito Federal. México. www.conagua.gob.mx. Dirección de Áreas Naturales y Vida Silvestre. Subsecretaría del Medio Ambiente. Gobierno de Mex.

[2] SEMARNAT. Norma Oficial Mexicana NOM-059-SEMARNAT-2010, Que Determina Las Especies y Subespecies de Flora y Fauna Silvestres Terrestres y Acuáticas en Peligro de Extinción, Amenazadas, Raras y las Sujetas a Protección Especial, y que Establece Especificaciones para su Protección. 30 de diciembre de 2010. México, Distrito Federal, México.

[3] Deutsch, C.J., Self-Sullivan, C. and Mignucci-Giannoni, A. Trichechus manatus. In: IUCN 2009. IUCNRed List of Threatened Species. Version 2009.2. <www.iucnredlist.org>. Consultado el 24 de diciembre de 2009.

[4] Colmenero R., L.C., and M.E. Hoz Zavala. Distribución de los manaties, situación y conservación en México. An. Inst. Biol. UNAM Serie Zoología (3) 955-1020, 1986.

[5] Olivera-Gómez, L.D. and D. Jiménez-Domínguez. Distribución y amenazas para la conservación del manatí (Trichechus manatus) en humedales de Tabasco. Congreso de la Sociedad Mexicana de Zoología. Villahermosa, Tab. Junio 2010.

[6] Rodas-Trejo, J., Romero-Berny., E.I. and Estrada A. Distribution and conservation of the West Indian manatee (Trichechus manatus manatus) 
in the Catazajá wetlands of northeast Chiapas, México. Mongabay.com Open Access Journal - Tropical Conservation Science Vol.1(4): 321-333, 2008.

[7] Folch J., Lees M. and Stanley G.H.S. A simple method for the isolation and purification of total lipids from animal tissues. Journal Biology and Chemistry 226. 497-509, 1957 Modificado por Izquierdo, información obtenida mediante comunicación personal, 2000.

[8] Lowry O.H., Rosenbrough N.J., Farr A.L. and Randall R.J. Protein measurement with the Folin phenol reagent. Journal of Biology. Chemistry 193: 265-272, 1951.

[9] Dubois M., Gilles K.A., Hamilton J.K., Rebers P.A. and Smith F. Colorimetric method for determination of sugar and related substances. Analytical Chemistry 28:350-356, 1956.

[10] Lichtenthaler, H.K. Chlorophyll and carotenoids: Pigments of Photosynthetic biomembranes. Methods Enzymol. 148: 350-382, 1987.

[11] AOAC. Official methods of analysis. Association of Official Analytical Chemists. Washington, DC, 1995.

[12] Gómez Lépiz A. Plantas Emergentes Y Flotantes En La Dieta Del Manatí (Familia: Trichechidae: Trichechus manatus) En El Caribe De Costa Rica.Rev. Mar. Cost. Issn 1659-455x. Vol. 2: 119-134, Diciembre 2010.

[13] Gutiérrez-Estrada M., Malpica-Cruz, V.M., Martínez-Reyes J. Geomorfología y Sedimentos Recientes Del Sistema Lagunar Atasta-Pom, Campeche, México. Anales del instituto de ciencias del mar y limnología, 1981.

[14] SEMARNAT Proyecto de conservación, recuperación y manejo del manatí Trichechus manatus en México. SERIE PREP núm. 11 Subsecretaría de Gestión para la Protección Ambiental2001. ISBN 968817-524-2 pp. 12-14. 